\title{
Grazing of two common appendicularians on the natural prey assemblage of a tropical coastal ecosystem
}

\author{
R. D. Scheinberg ${ }^{1, *}$, M. R. Landry ${ }^{2}$, A. Calbet $^{3}$ \\ ${ }^{1}$ Department of Oceanography, University of Hawaii at Manoa, Honolulu, Hawaii 96822, USA \\ ${ }^{2}$ Integrative Oceanography Division, Scripps Institution of Oceanography, La Jolla, California 92093-0227, USA \\ ${ }^{3}$ Institut de Ciències del Mar, CMIMA (CSIC), P. Marítim de la Barceloneta 37-49, 08003 Barcelona, Spain
}

\begin{abstract}
The clearance rates of co-occurring appendicularian species, Oikopleura longicauda and O. fusiformis, in Kaneohe Bay, Hawaii, were investigated to evaluate and compare their roles in a tropical food web. Individual appendicularians were captured in situ and allowed to feed on the natural plankton assemblage for 60 to $180 \mathrm{~min}$. Feeding rate estimates were based on flow-cytometry analyses of cell-density changes for heterotrophic bacteria (Hbact), Synechococcus spp. (Syn) and $<13.0 \mu \mathrm{m}$ autotrophic eukaryotes (Aeuks). Despite morphological differences, O. longicauda and $O$. fusiformis cleared the largest prey size-fraction at statistically indistinguishable rates. For the 3 prey categories (Hbact, Syn and Aeuks), mean clearance rates ( $\pm 95 \% \mathrm{CI}$ ) were $12 \pm 7,27 \pm 6$ and $34 \pm$ $18 \mathrm{ml}$ individual (ind.) $)^{-1} \mathrm{~h}^{-1}$ and $25 \pm 12,26 \pm 15$ and $38 \pm 20 \mathrm{ml}$ ind. ${ }^{-1} \mathrm{~h}^{-1}$ for O. longicauda and O. fusiformis, respectively. The mean clearance rates of these 2 species on total sub-micron cells in Kaneohe Bay were not significantly different; however, O. fusiformis cleared Hbact at a marginally higher rate $(\mathrm{p}=0.07)$. Only $O$. longicauda exhibited significantly different retention efficiencies as a function of prey size, clearing the smallest prey (Hbact) at approximately $36 \%$ the rate of the largest (Aeuks) ( $\mathrm{p}<0.01)$. Despite reduced efficiencies on the smallest prey categories, at high abundances in Kaneohe Bay (often 2 ind. $\mathrm{l}^{-1}$ ), O. longicauda is capable of removing $>60 \%$ of the picoplankton standing stock from the water column daily. While generally much less abundant, during occasional peaks of 1 ind. $\mathrm{l}^{-1}$, O. fusiformis can remove an almost equivalent amount (>50\%). Nevertheless, the consistently higher abundances of $O$. longicauda make this species a more significant link between picoplankton production and higher-level consumers (chaetognaths and fishes) in this coastal tropical embayment.
\end{abstract}

KEY WORDS: Appendicularian · Grazing · Clearance rates · Oikopleura spp.

\section{INTRODUCTION}

Tropical waters have complex multi-level food webs in which most production originates from, or passes through, prokaryotes and is dissipated through multiple levels of transfer via a protistan grazing chain (e.g. Azam et al. 1983, Calbet et al. 2001, Landry \& Kirchman 2002). It has been noted, however, that certain metazoans with the ability to feed directly on bacteriasized particles could short-circuit much of the microbial loop, eliminating several trophic steps (Turner et al. 1998). If so, such organisms could be disproportionately important to higher-level consumers and a potentially significant energy pathway in tropical plankton systems.

Appendicularians are small pelagic tunicates with this short-circuiting potential. Their mucous 'houses' include complex internal filtering-structures made of fine glycoprotein and carbohydrate filaments, which can retain particles as small as $0.13 \mu \mathrm{m}$ in diameter (Flood et al. 1992, Deibel 1998). They are themselves subject to predation by a wide variety of vertebrates and inverte- 
brates, such as larval fishes and chaetognaths (Shelbourne 1962, Kimmerer 1984, for review see Purcell et al. 2004). Appendicularians therefore bridge a relatively wide size range of food web components.

While it has been previously suggested that the large, gelatinous feeding structures of pelagic tunicates are of oligotrophic environments (Harbison 1992, Acuña 2001), distinct morphological differences in these structures among appendicularian species (Alldredge 1977) suggest that there may be unique adaptations to particular niches within the oligotrophic environment. Although numerous studies have investigated the rates at which appendicularians can clear and/or ingest particles from temperate, subarctic and arctic waters (Acuña et al. 1999, López-Urrutia et al. 2003, Fernández et al. water species (Alldredge 1977, 1981, Sato et al. 2004) and almost all utilized proxies for natural prey, such as latex beads or ink particles.

The goal of our study was to determine the relative rate capabilities of 2 common warm-water appendicularians, Oikopleura longicauda and $O$. fusiformis, grazing on natural prey, and to gain more insight into the reasons for their relative abundances in tropical waters. These species have distinct morphological characteristics with respect to the size and structure of their mucous feeding apparatus. The most remarkable of these differences are the unique absence of house a general adaptation to the low food concentrations 2004), only a handful have been conducted with warm-

inlet-filters for $O$. longicauda and the larger house-tobody size ratio of $O$. fusiformis, which is approximately twice that of $O$. longicauda (Fig. 1). The larger house size and internal filtering area of $O$. fusiformis suggests that its maximum filtering capability should exceed that of $O$. longicauda. The $\sim 1 \mathrm{~mm}$ inlet holes of $O$. longicauda are 2 orders of magnitude greater in diameter than the $13 \mu \mathrm{m}$-mesh filters of $O$. fusiformis (Alldredge 1977). O. longicauda also possesses a unique mucous hood that covers the entirety of its trunk and may afford it some as yet undetermined advantage during grazing (e.g. Alldredge 1977). It is possible, for example, that such a hood could help to deflect or shield the appendicularian from potentially harmful large cells that occasionally enter through its unrestricted inlets, although it should not be as effective as the inlet filters of $O$. fusiformis in preventing internal filter clogging by large cells.

While these 2 species are commonly considered to be warm-water species, they are found in almost every ocean with the exception of the Arctic, and tend to be among the most abundant appendicularians wherever they occur (Fenaux et al. 1998). In fact, Oikopleura longicauda is often reported as the dominant appendicularian in both coastal and open-ocean waters (Lohmann \& Hentschel 1939, Tokioka 1960, Fenaux 1968, Fenaux \& Dallot 1980, Taguchi 1982, Tomita et al. 2003) and has been observed in swarms of up to 3600 ind. $1^{-1}$ (Owen 1966, Alldredge 1982). In addition to their numerical domi- (a)
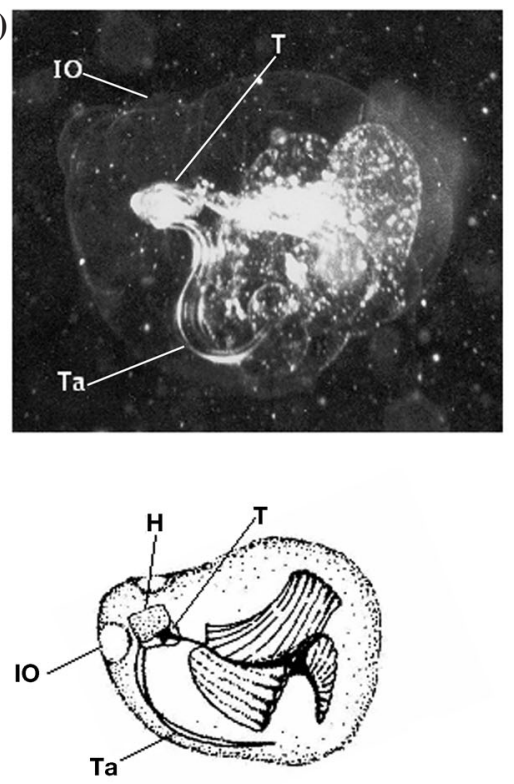

$5 \mathrm{~mm}$ (b)
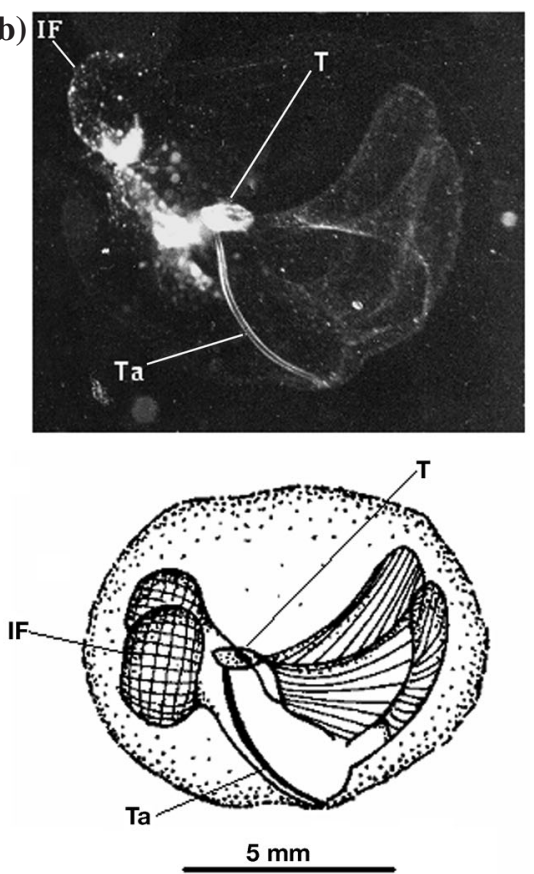

Fig. 1. (a) Oikopleura longicauda and (b) O. fusiformis in houses. T: trunk; Ta: tail; IO: incurrent opening; IF: incurrent filter; $\mathrm{H}$ : hood. Hood of $O$. longicauda is not visible in (a). Images courtesy of A. Alldredge; line drawings modified from Alldredge (1977) nance, López-Urrutia et al. (2003) recently found that these 2 species together had the greatest grazing impact among appendicularians on phytoplankton populations in the temperate open ocean. However, based on the relative temporal and spatial distributions of $O$. longicauda and $O$. fusiformis, it appears that they may be maximally successful under different environmental conditions (Acuña \& Anadón 1992, Acuña 1994, Fenaux 1998, Scheinberg 2004).

It has previously been determined that Oikopleura fusiformis, with its small body size and disproportionately large house, is well adapted for exploiting ultraoligotrophic waters dominated by picoplankton at low standing biomass (Scheinberg \& Landry 2004). However, despite the apparent success of $O$. fusiformis in openocean influenced waters along the 
NW coast of Oahu, this species is less abundant than $O$. longicauda in coastal sites with a greater terrestrial influence, higher nutrient concentrations and reduced circulation. To better understand the ecological importance of these species in tropical environments, feeding experiments were conducted in a mesotrophic embayment. Experiments were conducted to measure clearance rates on natural picoplankton and nanoplankton prey, and a sampling station was established to determine relative abundances during the experimental period. Our findings suggest that differences in house structure, and possibly tail length, width and musculature, may allow $O$. longicauda to deal better with higher prey concentrations and episodic blooms.

\section{MATERIALS AND METHODS}

Study site and sampling protocol. Fig. 2 shows a map of our sampling and experimental study sites in southern Kaneohe Bay on the NE coast of Oahu, Hawaii. The sampling station was chosen based on its highly representative nature with respect to the plankton community of the southern Kaneohe basin. Results from 8 mo of weekly sampling at 4 approximately equidistant stations in southern Kaneohe Bay indicated that the plankton community at Stn SB was not significantly different from the experimental site used in the present study (Student's $t$-test, $\mathrm{p}>0.05 ; \mathrm{R}$. Scheinberg unpubl. data). Sampling was conducted approximately every $2 \mathrm{wk}$ over a 5 mo period prior to and following appendicularian feeding experiments (see next subsection) to determine the relative biomass and abundances of Oikopleura longicauda and $O$. fusiformis. Gentle vertical tows were made from $12 \mathrm{~m}$ (station depth $15 \mathrm{~m}$ ) with a $0.5 \mathrm{~m}$ diameter $(64 \mu \mathrm{m}$ Nitex mesh) conical plankton net to minimize damage to the fragile gelatinous animals. The net was equipped with a polyvinyl chloride cod-end bucket with $64 \mu \mathrm{m}$ Nitex mesh windows for filtration. The small mesh allowed the collection of all life-history sizes, beginning with the first developmental stage after hatching (Fenaux 1998). Net tow samples were preserved in the field with borax-buffered formalin (5\% final concentration). In the laboratory, a minimum of 100 individuals of each species were counted and measured. Water samples were also collected every $3 \mathrm{~m}$ from the surface to $12 \mathrm{~m}$ using a 11 Niskin bottle. For chlorophyll a analyses, $25 \mathrm{ml}$ aliquots were filtered onto Whatman GF/F glass-fiber filters, and pigments were extracted in $5 \mathrm{ml}$ of $90 \%$ acetone in the dark at $-20^{\circ} \mathrm{C}$ for $24 \mathrm{~h}$. Chlorophyll a was quantified using a TD 700 fluorometer calibrated against HPLCdetermined concentrations (Holm-Hansen \& Riemann 1978).

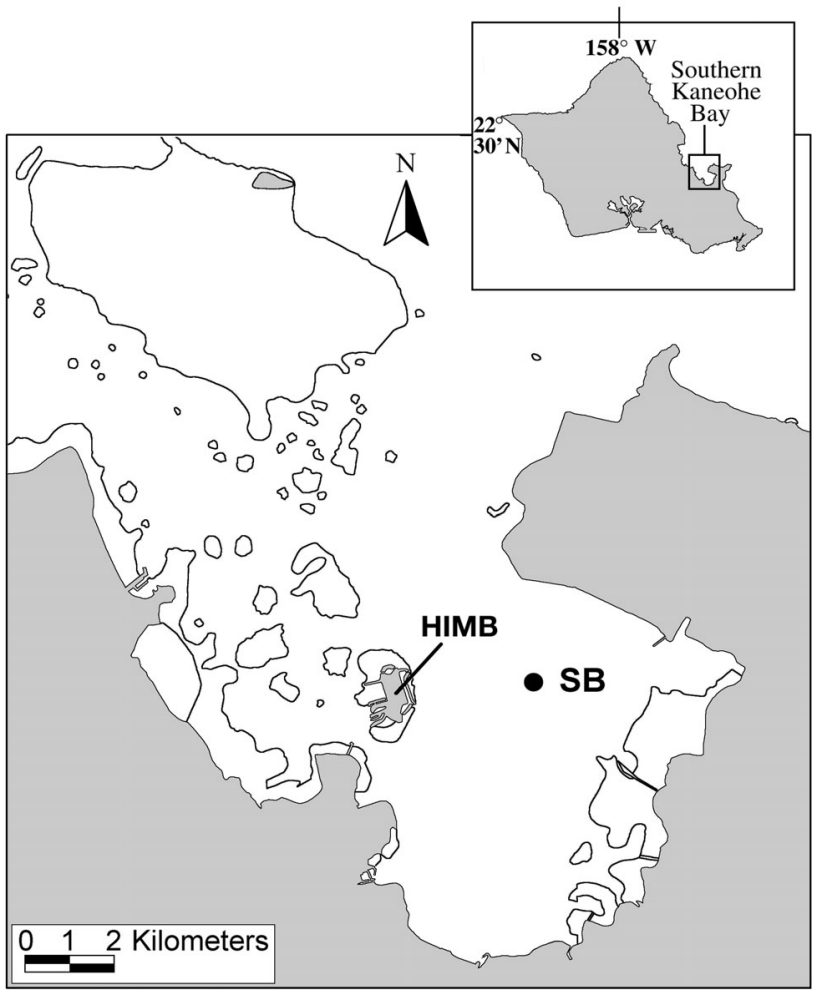

Fig. 2. Map of southern Kaneohe Bay, Hawaii study site. SB: routine sampling station; HIMB: Hawaii Institute of Marine Biology on Coconut Island

Feeding experiments. Grazing impacts of Oikopleura longicauda and $O$. fusiformis were investigated using individuals and seawater collected from a deep channel approximately $10 \mathrm{~m}$ offshore on Coconut Island in Kaneohe Bay. Field experiments were conducted in February and March 2002 to determine clearance rates on heterotrophic bacteria, Synechococcus spp. and autotrophic eukaryotes. Individual appendicularians were gently captured in situ in $265 \mathrm{ml}$ wide-mouth, polycarbonate bottles. Each experiment $(n=10)$ consisted of 2 to 4 bottles with 1 appendicularian each and 2 control bottles with ambient seawater without appendicularians. All bottles were incubated onshore in plastic chambers maintained at ambient temperature $\left(24 \pm 1^{\circ} \mathrm{C}\right)$ by periodic addition of seawater to the chambers. Incubation times ranged from 60 to $180 \mathrm{~min}$. Prior to incubation, initial $1 \mathrm{ml}$ aliquots were taken from each bottle, preserved in cryogenic tubes with paraformaldehyde (PFA; $4 \%$ final concentration) and frozen in liquid nitrogen for later analysis of picoplankton prey abundance. Additional $1 \mathrm{ml}$ aliquots were taken from each bottle approximately every 60 min, or until the appendicularian no longer maintained a steady feeding current in an inflated house. Aliquots of $50 \mathrm{ml}$ were also removed from each bottle prior to incubation and upon termination of the experiments. These 
samples were preserved with PFA (4\% final concentration) and stored on ice for later analysis of nanoplankton prey. After the experiments were terminated, the appendicularians were removed from the bottles, preserved (borax-buffered formalin; $5 \%$ final concentration) and brought back to the nearby laboratory (Hawaii Institute of Marine Biology) for immediate measurement and identification.

Appendicularians were identified according to Bückmann \& Kapp (1975) and Fenaux (1993) and measured to the nearest $20 \mu \mathrm{m}$ using a Leica MZ 9.5 stereomicroscope with an ocular ruler. Appendicularian trunk length was defined as the distance from the tip of the mouth to the posterior edge of the trunk. Shrinkage of preserved specimens was determined by measuring 50 live individuals and then re-measuring them up to $1 \mathrm{yr}$ following preservation. Biomass estimates were determined from the ash-free dry weight $(\mathrm{W}, \mu \mathrm{g})$ to trunk length (TL, $\mu \mathrm{m}_{i}$ corrected for shrinkage) relationships of Hopcroft et al. (1998) for Oikopleura longicauda, $\log \mathrm{W}=2.47 \log \mathrm{TL}-6.10$, and Alldredge (1976) for $O$. fusiformis, $\log \mathrm{W}=4.21 \log \mathrm{TL}-11.35$, as reported in Hopcroft et al. (1998). Biomass was converted to carbon (C) assuming a C:W ratio of 0.52 , as in Alldredge (1981). House lengths were estimated using the house length (L) to trunk length $(\mathrm{T})$ relationships of Alldredge (1977), where $\mathrm{L}=4.1 \mathrm{~T}+1.2$ for $O$. longicauda and $\mathrm{L}=9.9 \mathrm{~T}-0.4$ for $O$. fusiformis.

Measurement of clearance rates. Clearance rates were determined from changes in prey cell densities over the incubation period as measured using flowcytometry (FCM). Frozen $1 \mathrm{ml}$ aliquots from the grazing experiments were thawed and stained with Hoechst $33342\left(0.8 \mathrm{\mu g} \mathrm{m}^{-1}\right.$ final concentration) for 30 min before analysis (Monger \& Landry 1993). Each aliquot was spiked with a mixture of Polysciences Fluoresbrite YG 0.57 and $0.98 \mu \mathrm{m}$ visible-beads and $0.46 \mu \mathrm{m}$ UV-beads to normalize light-scatter signals to consistent size references. Subsamples of $100 \mu$ were enumerated on a Coulter EPICS 753 flow cytometer equipped with dual argon lasers and MSDS II automatic sampling. The lasers were aligned colinearly with the first laser tuned to the UV range to excite Hoechst-stained DNA. The second laser was tuned to $488 \mathrm{~nm}$ at $1.0 \mathrm{~W}$ to excite the pigments of autotrophic cells. Picoplankton populations were distinguished from each other by differences in light-scatter and fluorescence emission. Heterotrophic bacteria (Hbact) showed DNA staining but no red $(680 \pm 40 \mathrm{~nm})$ fluorescence. Synechococcus spp. (Syn) were characterized by the presence of orange $(575 \pm 40 \mathrm{~nm})$ fluorescence (phycoerythrin), and autotrophic eukaryotes (Aeuks) were identified by higher forward and right-angle light-scattering (indices of cell size) and enhanced red fluorescence compared to Syn.
Prey size and carbon estimates. The size composition of prokaryotic and eukaryotic prey was determined using both epifluorescence microscopy and flowcytometry according to the methods of Scheinberg \& Landry (2004). To avoid problems in distinguishing Syn from other groups of larger, phycoerythrincontaining cells microscopically, Syn size was determined via FCM analysis of size-fractionated water from Kaneohe Bay. Picoplankton prey abundance was converted to biomass equivalents using biovolume to carbon conversion factors of $380 \mathrm{fg}^{-3}$ (Lee \& Fuhrman 1987) and $235 \mathrm{fg}^{-3} \mathrm{~m}^{-3}$ (Shalapyonok et al. 2001) for Hbact and Syn, respectively. Biovolumes of autotrophic eukaryotes $\left(\mathrm{BV}, \mu^{3}\right)$ were converted to biomass (pg C) based on Eppley et al. (1970): $\log _{10}($ pg $C)=0.76 \log _{10}(B V)-0.29$ and $\log _{10}($ pg C $)=$ $0.94 \log _{10}(\mathrm{BV})-0.60$ for diatoms and flagellates, respectively. These equations do not take into account cell shrinkage due to preservation and thus yield minimum estimates of cell carbon content. We set an upper limit to prey size of $13 \mu \mathrm{m}$ (maximum diameter) for the purposes of a clearance rate comparison between Oikopleura longicauda and O. fusiformis, based on the house inlet-filter pore size of $O$. fusiformis (Flood \& Deibel 1998). This upper limit may have led to an underestimation of the possible impact of $O$. longicauda on $>13.0 \mu \mathrm{m}$ prey. Total available prey biomass was determined as the sum of the carbon estimates for picoplankton categories plus those from microscopic analyses of $<13 \mu \mathrm{m}$ autotrophic and heterotrophic nanoplankton.

Clearance and ingestion rate calculations. Clearance rates were calculated according to the equations of Frost (1972). Clearance rates, defined as the volume of water effectively cleared of a particular particle size by both the house and the tunicate over time (Deibel 1998), were determined from the rates of disappearance of cells in experimental incubations relative to controls. Successful experiments were defined as those with actively feeding appendicularians, interpreted as experiments that resulted in a measurable decrease $(>2 \%)$ in the largest prey-size fraction, Aeuks. This size fraction was chosen as the determining factor based on the results of previous experiments on Oikopleura fusiformis, which showed that the large cells were retained with maximum efficiency (Scheinberg \& Landry 2004). The number of houses produced during the incubation period was multiplied by the house-production time (approx. 1 min; R. Scheinberg unpubl. data) and subtracted from the total incubation time to determine net grazing time. Clearance rates for heterotrophic eukaryotes (Heuks) were assumed to be equivalent to the measured clearance rates on similarly sized Aeuks, and the biomass components of auto- and heterotrophs were combined $($ Euks $=$ total $<13 \mu \mathrm{m}$ eukaryotes) to 
calculate ingestion rates. Statistically significant differences between mean cell-density changes in control and experimental bottles were determined using paired $t$-tests at $\mathrm{p}=0.05$. Coefficients of variation of replicate FCM abundance estimates averaged $1.5 \%$ for natural bacterial concentrations (Monger \& Landry 1993). Experiments with a $<2 \%$ change in any prey category between initial and final samples were considered to have zero net change. Relative clearance efficiency was calculated assuming a maximum efficiency of $100 \%$ for $>1.0 \mu \mathrm{m}$ prey (Scheinberg \& Landry 2004).

Ingestion rates of Oikopleura longicauda and O. fusiformis were determined indirectly using measured clearance rates and assuming that $30 \pm 5 \%$ of the particles cleared were retained on the filtering apparatus and not ingested, as determined by Gorsky (1980) and Gorsky et al. (1984). This number is close to the mean of the range of 0 to $80 \%$ particulate adhesion reported in the literature (Acuña \& Kiefer 2000). The size-specific and taxon-specific adhesion of particles to appendicularian houses is unknown. The fraction of cleared cells that adhere to the mucous house and do not enter the pharynx of the tunicate was thus assumed to be independent of both size and prey taxon. In addition, it was assumed that Synechococcus spp. passed through the appendicularian gut intact (Gorsky et al. 1999) and were returned intact to the environment in fecal pellets without contributing to the nutrition of the organism. Synechococcus spp. was thus excluded from the calculation of total daily ration. All margins of error represent the $95 \%$ confidence intervals for the mean estimates.

\section{RESULTS}

\section{Prey community composition}

The abundance, size and biomass estimates of appendicularian prey during the grazing experiments are reported in Table 1. The smallest size fraction of prey, Hbact, dominated in abundance and was the only prey type for which abundance varied signifi-

Table 1. Mean size ranges ( $\mu \mathrm{m}, \mathrm{n} \geq 100$ ), abundances (cells $\mathrm{ml}^{-1}$ ), and biomass concentrations ( $\mu \mathrm{g} \mathrm{Cl}^{-1}$ ) of appendicularian prey during experimental period. Abundance and biomass of heterotrophic bacteria was significantly different $(p<0.001)$ over 2 of the experimental days and is thus presented as a range of values

\begin{tabular}{|lccc|}
\hline Prey type & Size & Abundance & Biomass \\
\hline Heterotrophic bacteria & $0.3-0.7$ & $2.5-4.6 \times 10^{5}$ & $2.7-8.7$ \\
Synechococcus spp. & $0.8-1$ & $1330 \pm 890$ & $1.4 \pm 0.1$ \\
Autotrophic eukaryotes & $1-13$ & $1720 \pm 120$ & $8.0 \pm 1.1$ \\
Heterotrophic eukaryotes & $1-13$ & $1970 \pm 760$ & $6.6 \pm 2.2$ \\
\hline
\end{tabular}

cantly over the experimental period (Fig. $3 ; p<0.001$ ). Although least abundant, small eukaryotes dominated in terms of biomass, with a mean of $8.0 \pm 1.1 \mu \mathrm{g} \mathrm{Cl}^{-1}$ for autotrophs and $6.6 \pm 2.2 \mu \mathrm{g} \mathrm{Cl}^{-1}$ for heterotrophs. Net growth rates of $0.06 \pm 0.02$ and $0.03 \pm 0.01 \mathrm{~d}^{-1}$ were measured in experimental controls for heterotrophic bacteria and Synechococcus spp., respectively. There was no significant change in prey abundance in the controls for Aeuks $(p>0.1)$. Epifluorescence microscopy and FCM-analyzed size-fractionation experiments were used to determine the size range of each prey category. Prey size varied little over the experimental period. The mean equivalent spherical diameters (ESDs) of $<13 \mu \mathrm{m}$ eukaryotes were $3.6 \pm 0.3$, $4.0 \pm 0.1$ and $3.3 \pm 0.2$ on February 20 (Experimental Day 1), February 21 (Day 2) and March 11 (Day 3), respectively. Hbact had a mean ESD of $0.5 \pm 0.03 \mu \mathrm{m}$ and approximately $93 \%$ of all Syn were between 0.8 and $1.0 \mu \mathrm{m}$ in diameter.

Chlorophyll a concentrations ranged from 0.2 to $1.6 \mu \mathrm{g}$ $\mathrm{l}^{-1}$ in Kaneohe Bay between January and May, with a mean of $0.8 \pm 0.3 \mu \mathrm{g} \mathrm{l}^{-1}(\mathrm{n}=9)$. The maximum coincided with blooms of the large, chain-forming diatoms Chaetocerus spp. and the dinoflagellates Ceratium spp. on Experimental Days 1 and 2, respectively. Day 3 had a comparable chlorophyll a concentration of $1.3 \mu \mathrm{g} \mathrm{C}^{-1}$.

\section{Appendicularian community composition}

Analyses of net-collected samples confirmed the presence of either Oikopleura longicauda or O. fusiformis in each of the experimental bottles. In addition,

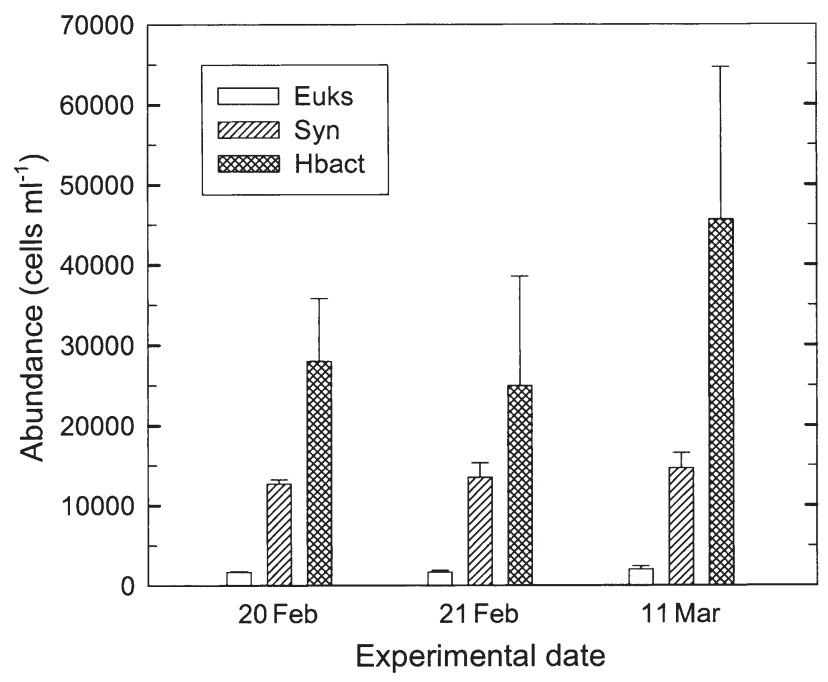

Fig. 3. Abundance of heterotrophic bacteria (Hbact), Synechococcus spp. (Syn). and $<13.0 \mu \mathrm{m}$ eukaryotes (Euks) in Kaneohe Bay, Hawaii, over 3 experimental days. Error bars represent upper $95 \%$ confidence intervals of the mean $(n=26)$ 
analyses of net samples from southern Kaneohe Bay established that they were the only 2 appendicularian species in the bay over the 5 mo sampling period. Details on the size, biomass and abundance of these species are given in Table 2. O. longicauda dominated the appendicularian community in terms of abundance during all grazing experiments and on 9 out of 10 sampling days (Fig. 4). Peak appendicularian abundance ( 2.6 ind. $\mathrm{l}^{-1}$ ) occurred on Day 3 of the experiment. The sizes of the experimental individuals, as indicated by trunk length (TL), were representative of the general appendicularian population, with a range of 0.4 to $0.9 \mathrm{~mm}$ (mean $=0.7 \pm 0.2$ ) and 0.4 to $1.0 \mathrm{~mm}$ (mean = $0.8 \pm 0.2$ ) for $O$. longicauda and $O$. fusiformis, respectively. The sizes of both species were corrected using the mean shrinkage value of $13 \pm 2 \%$. Mean biomass was $2.8 \pm 1.9 \mu \mathrm{gC}$ ind. ${ }^{-1}$ for $O$. longicauda and $4.2 \pm$ $2.6 \mu \mathrm{g} \mathrm{C}$ ind.$^{-1}$ for $O$. fusiformis. Despite similarities in $\mathrm{TL}$, adult $O$. longicauda had a wider and more muscular tail than $O$. fusiformis, and the mean house length of $O$. fusiformis was almost 2 times larger than that of O. longicauda $(7.0 \pm 1.3$ vs. $3.9 \pm 0.5 \mathrm{~mm})$.

\section{Clearance rates}

Appendicularians exhibited significant feeding in $61 \%$ of the grazing bottles. Failure to build a new house following capture was the most common reason for the lack of feeding. Only the results of successful experiments are given here, i.e. those in which the tunicates built a new house following capture and were observed to maintain a steady feeding current. Experimental bottles contained an average of $1.2 \pm 0.5$ discarded houses. Clearance rates were variable, but did not differ significantly between experimental dates for Oikopleura longicauda $(\mathrm{n}=10)$ or $O$. fusiformis $(\mathrm{n}=7)$ ( $p>0.1$; Fig. 5). Clearance rates are not reported for $O$. longicauda on Day 3 of the experiment, as terminal bloom conditions of this species prevented the collection of healthy, feeding individuals. Mean clearance rates on each prey type over the experimental period are illustrated in Fig. 6. O. longicauda exhibited their highest clearance rates on the largest size fraction of prey, Aeuks, with a maximum rate of $85 \mathrm{ml}^{-1}$ ind $^{-1} \mathrm{~h}^{-1}$ (mean $=34 \pm 18 \mathrm{ml}$ ind. ${ }^{-1} \mathrm{~h}^{-1}$ ), and cleared both Aeuks and Syn at significantly higher rates than Hbact (mean $=12 \pm 7 \mathrm{ml}$ ind..$^{-1} \mathrm{~h}^{-1} ; \mathrm{p}<$ 0.05). Mean clearance rates on Aeuks and Syn were not statistically different $(p>0.1)$. In contrast, $O$. fusiformis cleared all prey at statistically indistinguishable rates (range $=6$ to $78 \mathrm{ml}$ ind.$^{-1} \mathrm{~h}^{-1}$, mean $=$ $30 \pm 9 \mathrm{ml}$ ind. ${ }^{-1} \mathrm{~h}^{-1}, \mathrm{p}>0.1$ ). Despite their different size-dependent tendencies, $O$. longicauda and $O$. fusiformis did not clear any of their prey fractions at statistically different rates from each other $(p>0.05)$. A p-value of 0.07 for the comparative clearance rate of Hbact by both species suggests that this smallest size fraction may be an exception. The single rate measured for $O$. fusiformis on Experimental Day 3 fell within 2 standard deviations of the mean for all prey types on the first 2 experimental days and is thus included in our results. Our small sample size did not allow us to determine a significant relationship between trunk length and clearance rate for either species.

\section{Ingestion estimates}

Based on measured clearance rates and our assumptions regarding size- and taxon-independent cell losses to house adhesion, Oikopleura longicauda and O. fusiformis ingested the majority of their carbon from the largest and least abundant size fraction of planktonic prey, 1 to $13 \mu \mathrm{m}$ Euks. For both species, ingestion rates of eukaryotic prey were significantly higher than for all other prey combined on all experimental days $(\mathrm{p}<0.05$, Fig. 7). Although assumed to be indigestible, Synechococcus spp. is included in Fig. 7 to illustrate the potential magnitude of carbon removal for this size fraction of prey. Hbact and Euks represent the total

Table 2. Oikopleura longicauda and O. fusiformis. Size distribution, weight, house diameter, filter mesh, abundances and biomass of the 2 species of appendicularian in Kaneohe Bay, Hawaii. For size and abundance, $n \geq 100$. Tail width represents tail-muscle band and excludes the often-damaged fin-like expansions on both sides. Individual biomass and house lengths were calculated from trunk length according to relationships of Alldredge (1976) and Alldredge (1977), respectively. nd: no data

\begin{tabular}{|c|c|c|c|c|}
\hline \multirow[t]{2}{*}{ Species } & \multicolumn{2}{|c|}{ O. longicauda } & \multicolumn{2}{|c|}{ O. fusiformis } \\
\hline & Range & Mean \pm CI & Range & Mean \pm CI \\
\hline Trunk length (mm) & $0.4-0.90$ & $0.7 \pm 0.1$ & $0.4-1.0$ & $0.8 \pm 0.2$ \\
\hline Tail width (mm) & $0.07-0.50$ & $0.2 \pm 0.03$ & $0.04-0.30$ & $0.2 \pm 0.04$ \\
\hline Tail length (mm) & $0.8-6.0$ & $2.7 \pm 0.5$ & $0.8-5.1$ & $2.4 \pm 0.6$ \\
\hline Body wt ( $\mu$ g C ind.$^{-1}$ ) & $0.9-8.8$ & $2.8 \pm 2.0$ & $0.2-9.2$ & $4.8 \pm 2.6$ \\
\hline House diameter (mm) & $2.7-5.0$ & $3.9 \pm 0.5$ & $3.6-9.3$ & $7.0 \pm 1.3$ \\
\hline \multicolumn{5}{|l|}{ Inlet-filter mesh } \\
\hline length $\times$ width $(\mu \mathrm{m})$ & & \multicolumn{2}{|c|}{$13 \times 13^{\mathrm{a}}$} \\
\hline $\begin{array}{l}\text { Food-concentrating filter } \\
\text { mesh }^{\mathrm{b}} \text { length } \times \text { width }(\mu \mathrm{m}\end{array}$ & \multicolumn{2}{|c|}{$610 \times 150^{c}$} & \multicolumn{2}{|c|}{ nd } \\
\hline Abundance (ind. $\mathrm{l}^{-1}$ ) & $0.01-2.60$ & $1.2 \pm 0.5$ & $0.00-0.90$ & $0.3 \pm 0.2$ \\
\hline Biomass $\left(\mu \mathrm{g} \mathrm{C} \mathrm{l}^{-1}\right)$ & $0.02-3.70$ & $1.8 \pm 0.1$ & $0.00-1.40$ & $0.4 \pm 0.1$ \\
\hline
\end{tabular}




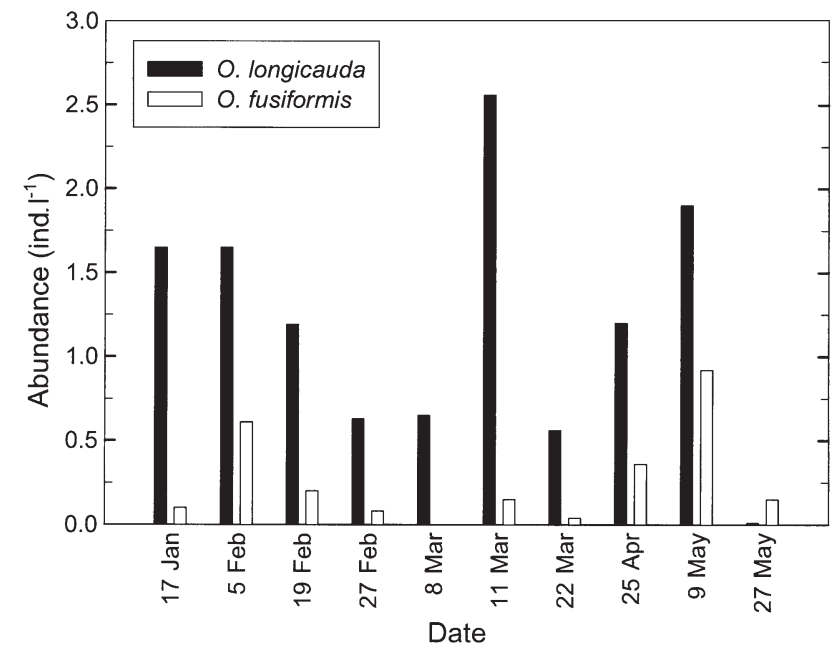

Fig. 4. Oikopleura longicauda and O. fusiformis. Abundance in southern Kaneohe Bay over a 5 mo period

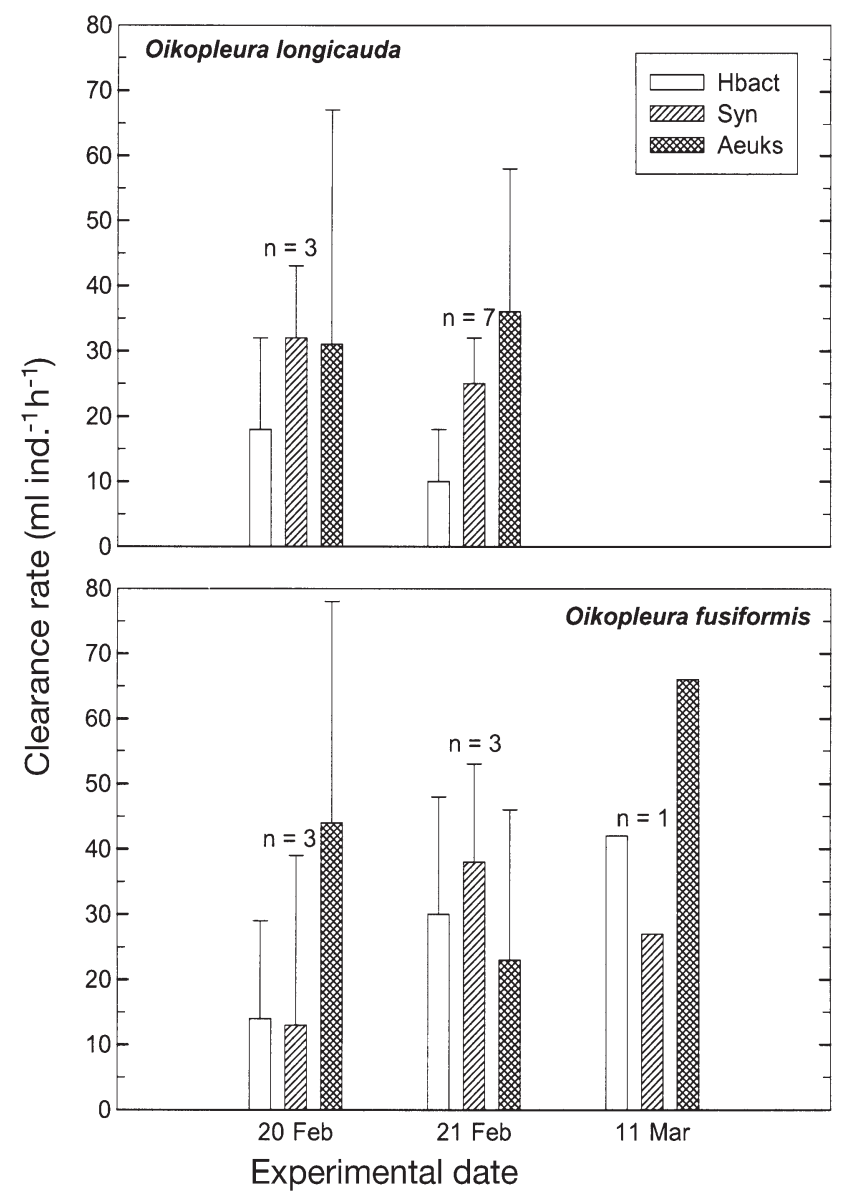

Fig. 5. Oikopleura longicauda and O. fusiformis. Clearance rates of heterotrophic bacteria (Hbact), Synechococcus spp. (Syn) and <13.0 $\mu \mathrm{m}$ autotrophic eukaryotes (Aeuks) on 3 experimental days ( $\mathrm{n}=$ no. of experimental bottles). Error bars represent upper $95 \%$ confidence intervals of the mean digestible prey in mean ingestion rate and daily ration calculations for $O$. longicauda and $O$. fusiformis. Mean rates did not differ significantly over the experimental period ( $p>0.1)$ or between species $(p>0.5)$. O. longicauda had an overall mean ingestion rate of $0.4 \pm 0.2 \mu \mathrm{g} \mathrm{C}$ ind.$^{-1} \mathrm{~h}^{-1}$, while $O$. fusiformis ingested prey at a mean rate of $0.5 \pm 0.2 \mu \mathrm{g} \mathrm{C}$ ind..$^{-1} \mathrm{~h}^{-1}$. Weightspecific ingestion rates of $O$. longicauda were lower on the second experimental day, but were not statistically different between days $(\mathrm{p}>0.1, \mathrm{n}=10)$. Specific ingestion rates of $O$. fusiformis did vary significantly, rang-

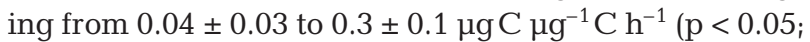
$\mathrm{n}=7$ ). Nonetheless, the daily rations of $O$. longicauda and $O$. fusiformis were not significantly different over the experimental period, at $4.6 \pm 2.6 \mu \mathrm{gC} \mu \mathrm{g}^{-1} \mathrm{C} \mathrm{d}^{-1}$ and $3.7 \pm 2.4 \mu \mathrm{gC} \mu \mathrm{g}^{-1} \mathrm{C} \mathrm{d}^{-1}$, respectively ( $\mathrm{p}>0.5$ ).

\section{DISCUSSION}

Our findings represent the first comparative feeding study of small, warm-water appendicularians on their natural prey assemblages. In addition, we report clearance rates of one of the most globally abundant oikopleurids, Oikopleura longicauda, on naturally occurring nano- and picoplankton prey. O. longicauda comprised $>80 \%$ of the abundance and biomass of appendicularians in Kaneohe Bay over the experimental period, yet, despite the relative abundances and morphological differences between the 2 species, $O$. longicauda and $O$. fusiformis cleared their largest size

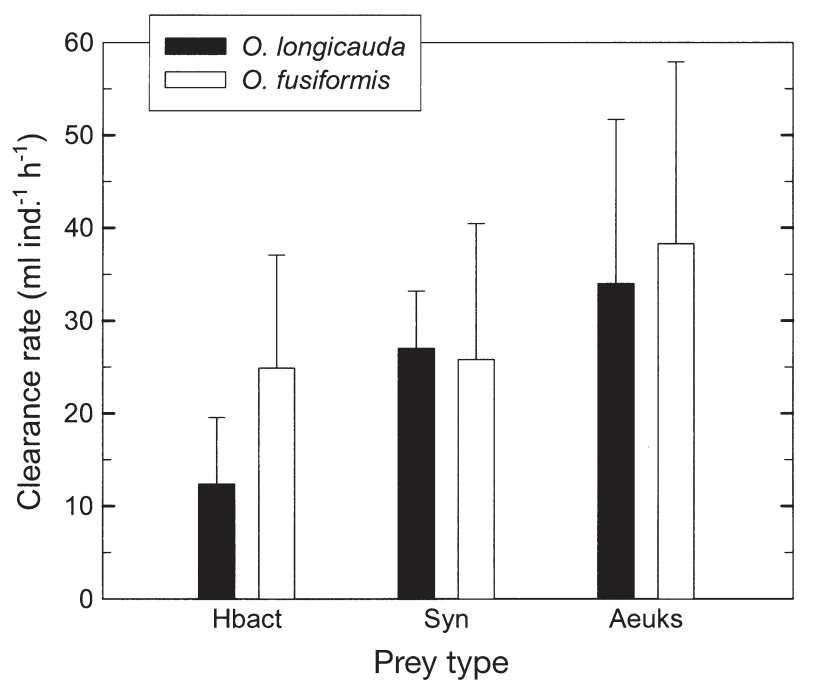

Fig. 6. Oikopleura longicauda and O. fusiformis. Mean clearance rates on heterotrophic bacteria (Hbact), Synechococcus spp. (Syn) and $<13.0 \mu \mathrm{m}$ autotrophic eukaryotes (Aeuks) over the experimental period. Error bars represent upper 95\% confidence intervals of the mean $(n=17)$ 


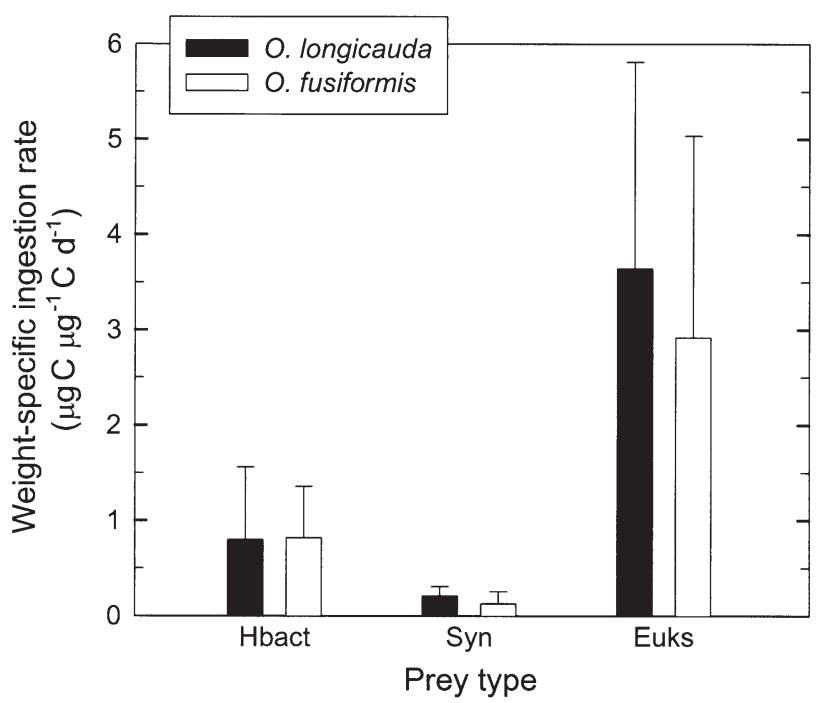

Fig. 7. Oikopleura longicauda and O. fusiformis. Weightspecific ingestion-rate estimates on heterotrophic bacteria (Hbact), Synechococcus spp. (Syn) and $<13.0 \mu \mathrm{m}$ eukaryotes (Euks) in Kaneohe Bay. Ingestion rates were determined indirectly using measured clearance rates and assuming that $30 \pm 5 \%$ of the particles cleared were retained on filtering apparatus and not ingested. Error bars represent upper 95\% confidence intervals of the mean

fraction of prey at statistically indistinguishable rates ( $p>0.5$; Fig. 6) and ingested comparable amounts of total prey carbon per body weight $(p>0.5)$. It thus appears that their abundance differences must be determined by factors other than their relative feeding capabilities.

\section{Clearance rates on nanoplankton}

The few studies that have investigated the feeding capabilities of both Oikopleura longicauda and O. fusiformis varied both in methodology and results (Alldredge 1977, López-Urrutia et al. 2003) (Table 3). López-Urrutia et al. (2003) found that O. longicauda and $O$. fusiformis ingested phytoplankton at comparable rates in temperate waters with chlorophyll a concentrations similar to those in Kaneohe Bay. In contrast, based on in situ estimates of water flow-through rates, Alldredge (1977) noted that O. fusiformis could process water at twice the rate of $O$. longicauda under warm temperature and low food conditions. We have similarly found discordant results for these species. In the present experiments in Kaneohe Bay, their feeding rates were very similar. In previous experiments with O. fusiformis from the NW coast of Oahu, however, their maximum clearance rates were substantially higher than in Kaneohe Bay $\left(143 \mathrm{ml}\right.$ ind..$^{-1} \mathrm{~h}^{-1}$; Scheinberg \& Landry 2004).
The virtually identical methods employed in our present and previous experiments and the differences in plankton size structure and biomass between our 2 study sites offer some potential insight into the responses of Oikopleura fusiformis to environmental conditions. The plankton community of Oahu's NW coast is typically dominated by sub-micron cells in terms of abundance and biomass, and chlorophyll a concentrations are comparable to ultra-oligotrophic waters of the central North Pacific subtropical gyre (mean $=0.23 \mu \mathrm{g} \mathrm{l}^{-1}$; Karl et al. 2002, Scheinberg \& Landry 2004). In contrast, our experiments in Kaneohe Bay were conducted at yearly maximum chlorophyll a concentrations (1.6 $\mathrm{gg} \mathrm{l}^{-1}$; Scheinberg 2004) during a bloom of relatively large, chain-forming diatoms (Chaetocerus spp.) and dinoflagellates (Ceratium spp.). Both chlorophyll a concentrations and the biomass of $<13.0 \mu \mathrm{m}$ cells were approximately 4 -fold higher in Kaneohe Bay than during our previous study.

There are 2 possible scenarios that may have led to the comparatively reduced clearance rates of Oikopleura fusiformis on large cells in Kaneohe Bay: (1) feeding saturation or (2) reduced inlet-filter porosity due to clogging. The comparable ingestion rates of O. fusiformis in mesotrophic Kaneohe Bay and oligotrophic NW Oahu suggest a saturated feeding response, other factors (e.g. particle adhesion and digestion efficiency) being assumed equal. Acuña \& Kiefer (2000) and Tiselius et al. (2003) observed such an effect for $O$. dioica feeding in temperate and subarctic waters, respectively. Although prey concentrations in their experiments were over 3 times those in our study, the saturated weight-specific ingestion rates for $O$. dioica $\left(0.16\right.$ and $0.20 \mu \mathrm{gC} \mu \mathrm{g}^{-1} \mathrm{C} \mathrm{h}^{-1}$, respectively) were remarkably similar to those of $O$. fusiformis in Kaneohe Bay and NW Oahu (0.15 and $0.21 \mu \mathrm{gC} \mathrm{gg}^{-1} \mathrm{C}^{-1}$, respectively). We would intuitively expect maximum specific ingestion rates of comparably sized appendicularians to be greater in warmer waters. However, the bulk ingestion rates of O. fusiformis are clearly understated in our estimates, which assume $30 \%$ house losses and do not account for the intake of indigestible Syn or detritus. Our results for $O$. fusiformis are therefore compatible with a foodsaturation feeding or processing explanation, but further research is needed to confirm if such a constraint actually exists and how it might be influenced by site differences in the quantity and quality of small suspended particulates.

As an alternative explanation, direct inhibition of appendicularian feeding by large diatoms has been observed by both Knoechel \& Steel-Flynn (1989) and Acuña et al. (1999), who found negative relationships between diatom abundance and clearance rates and gut fluorescence, respectively. Feeding inhibition was 
also observed by López-Urrutia et al. (2003) for Oikopleura fusiformis feeding in temperate waters during periods of increased large cell abundance within the chlorophyll a range of our experiments. Moreover, $O$. fusiformis was the only species in the study of Lópezurrutia et al. (2003) for which the abundance of $>30 \mu \mathrm{m}$ cells had a strong, statistically significant effect when total ingestion was considered (their Fig. 6). Selander \& Tiselius (2003) further determined that behavioral responses to the abundance of large cells, such as a decrease in tail beats $\mathrm{min}^{-1}$ and an increase in tail arrests $\min ^{-1}$ (the periodic arrest of tail motion during feeding), contributed to reduced clearance rates. The possibility of filter-clogging by large diatoms and dinoflagellates is consistent with the fact that the dominant genera, Chaetocerus spp. and Ceratium spp., both have particularly spiny cells or form chains that may stick to, and thus clog, the mucous inlet-filters of appendicularians (Tiselius et al. 2003). We thus suggest that the lower clearance rates of $O$. fusiformis on $>1.0 \mu \mathrm{m}$ cells in Kaneohe Bay compared to those previously measured off of the NW coast of Oahu are, at least in part, a consequence of abundant large, sticky cells in Kaneohe Bay.

\section{Clearance rates on picoplankton}

While both Oikopleura longicauda and O. fusiformis clear tropical waters of a wide range of prey sizes, the efficiency with which they remove different size fractions varies (Fig. 5). Of the 2 species in Kaneohe Bay, only $O$. longicauda exhibited significantly different clearance efficiencies relative to prey size, retaining Hbact at approximately $36 \%$ of the rate for Aeuks $(p<0.05)$. The variability in prey removal efficiencies cannot be explained by animal size, prey abundance or prey size. The most significant relationships observed were on the experimental day with the highest number of replicates $(O$. longicauda, Day 2). These results are similar to those found previously for $O$. fusiformis in oligotrophic waters off NW Oahu ( $\mathrm{n}=50$; Scheinberg \& Landry 2004), as well as in studies of $O$. dioica and $O$. vanhoeffeni using latex microspheres (Deibel \& Lee 1992, Fernández et al. 2004).

The mean clearance rates of Oikopleura fusiformis and $O$. longicauda on total sub-micron cells in Kaneohe Bay were not significantly different; however, a p-value of 0.07 suggests that $O$. fusiformis cleared Hbact at a higher rate. It thus appears that, despite its larger house size, $O$. fusiformis is at least as equally efficient as $O$. longicauda at retaining its smallest prey. Deibel \& Powell (1987) noted that the pore size of the internal food-concentrating filter tends to be related to trunk length, rather than to house size. The coarser pharyngeal filters (Deibel \& Lee 1992) may also have a similar porosity if particles that pass through this filter are not recirculated (Fernandez et al. 2004).

Since Oikopleura fusiformis did feed on sub-micron prey at relatively high rates in Kaneohe Bay, the lack of a clear size-efficiency trend may be less a consequence of altered behavior and more the result of physical clogging. While filter-clogging may have a direct negative impact on the removal of larger cells from the water column, it may not significantly alter the rate at which $O$. fusiformis feeds on sub-micron prey. Moreover, the cohesive properties of diatom and dinoflagellate exudates may enhance the retention efficiencies for bacterial prey beyond what would otherwise be expected given their small size. Elevated clearance rates on Hbact in Kaneohe Bay could also reflect a larger size of heterotrophic bacteria or differences in physiochemical properties of the cells (e.g. Monger et al. 1999). Consequently, when large cells are abundant

Table 3. Oikopleura longicauda and O. fusiformis. Comparison of estimated clearance rates $\left(\mathrm{ml}\right.$ ind. $\left.{ }^{-1} \mathrm{~h}^{-1}\right)$ (highest to lowest mean rates); clearance rates normalized to a trunk length of $1.0 \mathrm{~mm}$ assuming an exponential relationship between clearance rate and trunk length. Clearance rates from López-Urrutia et al. (2003) represent clearance of individual organisms and do not take into account particle adhesion to mucous houses. FCM: flow cytometry

\begin{tabular}{|c|c|c|c|c|c|}
\hline \multirow[t]{2}{*}{ Method (prey size) } & \multirow{2}{*}{$\begin{array}{c}\mathrm{T} \\
\left({ }^{\circ} \mathrm{C}\right)\end{array}$} & \multirow{2}{*}{$\begin{array}{l}\text { Trunk length } \\
(\mathrm{mm})\end{array}$} & \multicolumn{2}{|c|}{ Clearance rate } & \multirow[t]{2}{*}{ Source } \\
\hline & & & Measured & Normalized & \\
\hline \multicolumn{6}{|l|}{ O. longicauda } \\
\hline Natural prey $\left(\mathrm{FCM}_{i}>1.0 \mu \mathrm{m}\right)$ & 24 & $0.7 \pm 0.1$ & 34 & 35 & This study \\
\hline Gut chlorophyll content $(0.7-30 \mu \mathrm{m})$ & $13-15$ & 1.00 & $20^{\mathrm{a}}$ & 20 & López-Urrutia et al. (2003) \\
\hline Visual (dye) & 25 & $1.1 \pm 0.2$ & $36^{\mathrm{b}}$ & 36 & Alldredge (1977) \\
\hline \multicolumn{6}{|l|}{ O. fusiformis } \\
\hline Natural prey (FCM; >1.0 $\mu \mathrm{m})$ & 24 & $0.8 \pm 0.1$ & 38 & 39 & This study \\
\hline Natural prey $\left(\mathrm{FCM}_{i}>1.0 \mu \mathrm{m}\right)$ & 29 & $0.7 \pm 0.1$ & 143 & 147 & Scheinberg \& Landry (2004) \\
\hline Gut chlorophyll content $(0.7-30 \mu \mathrm{m})$ & $13-15$ & 1.00 & $14^{\mathrm{a}}$ & 14 & López-Urrutia et al. (2003) \\
\hline Visual (dye) & 25 & $0.6 \pm 0.1$ & $72^{\mathrm{b}}$ & 77 & Alldredge (1977) \\
\hline
\end{tabular}


during bloom conditions, $O$. fusiformis might have a disproportionate impact on prokaryotes than on larger eukaryotic prey.

\section{Relative grazing impact on the natural prey assemblage of tropical waters}

Oikopleura longicauda and $O$. fusiformis both ingest the majority of their carbon from $>1 \mu \mathrm{m}$ eukaryotic cells. Nonetheless, because of its abundance, their smallest prey category (Hbact) provides 12 and $22 \%$ of daily carbon intake for $O$. longicauda and $O$. fusiformis, respectively, the second largest contribution of the 3 prey groups. Although O. longicauda does not feed as efficiently on heterotrophic bacteria as it does on eukaryotic cells, at its common abundance of 1 ind. $1^{-1}$ seawater, it can still remove $30 \%$ of bacterial standing stock daily. Given that abundances often exceed 2 ind. $\mathrm{I}^{-1}$ in Hawaiian coastal waters (Scheinberg 2004), O. longicauda can potentially clear over $60 \%$ of the bacterial biomass from the water column on a daily basis. While $O$. fusiformis is typically less numerous than $O$. longicauda in Kaneohe Bay, it still reached densities of approximately 1 ind. $\mathrm{l}^{-1}$ during our 5 mo investigation. During such a peak, $O$. fusiformis can remove an almost equivalent amount ( $>50 \%$ ) of bacterial standing stock daily compared to O. longicauda because of its somewhat higher mean clearance rates on this size fraction. Thus, although both species are considered inefficient grazers on bacterioplankton with respect to their maximum clearance-rate capabilities, they can still function significantly as a direct trophic link from microbes to higher-level consumers, as well as a rich source of particulate organic material in the marine environment.

Perhaps not surprisingly, given the relative importance of picoplankton in tropical oceans, Oikopleura longicauda and $O$. fusiformis can clear naturally occurring prey in this size range at rates substantially higher than those of comparably sized appendicularians studied to date (King et al. 1980, Alldredge 1981, Bedo et al. 1993, Acuña \& Kiefer 2000, Broms \& Tiselius 2003, LópezUrrutia et al. 2003, Fernandez et al. 2004), and vastly exceeding the rates of co-occurring copepods (Calbet et al. 2000). In fact, grazing by $O$. longicauda can lead to mean picophytoplankton mortality rates comparable to those resulting from protozoan grazing (specifically 2 to $5 \mu \mathrm{m}$ heterotrophic nanoflagellates) in Kaneohe Bay (Landry et al. 1984, Scheinberg 2004). Of the 2 appendicularian species investigated in this study, the consistently high abundances of $O$. longicauda makes them a more likely candidate for transferring significant quantities of picoplankton production to higher-level consumers (chaetognaths and fishes; Kimmerer 1984, Clarke 1989) in coastal tropical waters.
Acknowledgements. We thank D. Ruplinger for her help with field experiments and K. Selph for her assistance in the analysis of flow-cytometry samples. We also thank S. Christensen, D. Hoover and 4 anonymous reviewers for their helpful comments on an earlier version of this manuscript. This work was funded by a grant/cooperative agreement from the National Oceanic and Atmospheric Administration, project \# RFM-9, which is sponsored by the University of Hawaii Sea Grant College Program, SOEST, under Institutional Grant No. NA16RG2254 from the NOAA Office of Sea Grant, Department of Commerce. The views expressed herein are those of the authors and do not necessarily reflect the views of NOAA or any of its subagencies. UNIHISEAGRANT-JC-03-08. This work was also supported by grant REN2001-1693, and Program Ramón y Cajal from the Ministry of Science and Technology of Spain (A.C.). Contribution No. 6593 from the School of Ocean and Earth Science and Technology, University of Hawaii at Manoa.

\section{LITERATURE CITED}

Acuña JL (1994) Summer vertical distribution of appendicularians in the central Cantabrian Sea (Bay of Biscay). J Mar Biol Assoc UK 74:585-601

Acuña JL (2001) Pelagic tunicates: why gelatinous? Am Nat 158:100-107

Acuña JL, Anadón R (1992) Appendicularian assemblages in a shelf area and their relationship with temperature. J Plankton Res 14:1233-1250

Acuña JL, Kiefer M (2000) Functional response of the appendicularian Oikopleura dioica. Limnol Oceanogr 45: 608-618

Acuña JL, Deibel D, Bochdansky AB, Hatfield E (1999) In situ ingestion rates of appendicularian tunicates in the Northeast Water polynya (NE Greenland). Mar Ecol Prog Ser 186:149-160

Alldredge AL (1976) Field behavior and adaptive strategies of appendicularians (Chordata: Tunicata). Mar Biol 38:29-39

Alldredge AL (1977) House morphology and mechanisms of feeding in the Oikopleuridae (Tunicata, Appendicularia). J Zool 18:175-188

Alldredge AL (1981) The impact of appendicularian grazing on natural food concentrations in situ. Limnol Oceanogr $26: 247-257$

Alldredge AL (1982) Aggregation of spawning appendicularians in surface windrows. Bull Mar Sci 32:250-254

Azam F, Fenchel T, Field JG, Meyer-Reil LA, Thingstad F (1983) The ecological role of water-column microbes in the sea. Mar Ecol Prog Ser 10:257-263

Bedo AW, Acuña JL, Robins D, Harris RP (1993) Grazing in the micron and the sub-micron particle size range: the case of Oikopleura dioica (Appendicularia). Bull Mar Sci 53:2-14

Broms F, Tiselius P (2003) Effects of temperature and body size on the clearance rate of Oikopleura dioica. J Plankton Res 25:573-577

Bückmann A, Kapp H (1975) Taxonomic characteristics used for the distinction of species of Appendicularia. Mitt Hamb Zool Mus Inst 72:201-228

Calbet A, Landry MR, Scheinberg RD (2000) Copepod ingestion rates in a subtropical bay: specific responses to a midsummer increase in the nanoplankton standing stock. Mar Ecol Prog Ser 193:75-84

Calbet A, Landry MR, Nunnery S (2001) Bacteria-flagellate interactions in the microbial food web of the oligotrophic subtropical North Pacific. Aquat Microb Ecol 23:283-292 
Clarke TA (1989) Species profiles: life histories and environmental requirements of coastal vertebrates and invertebrates, Pacific Ocean Region; Report 4: The Hawaiian anchovy or nehu Encrasicholina purpurea (Engraudlidae). Technical Report EL-89-10. US Army Engineer Waterways Experiments Station, Vichsburg, MS

Deibel D (1998) Feeding and metabolism of Appendicularia. In: Bone Q (ed) The biology of pelagic tunicates. Oxford University Press, Oxford, p 139-149

Deibel D, Lee SH (1992) Retention efficiency of sub-micrometer particles by the pharyngeal filter of the pelagic tunicate Oikopleura vanhoeffeni. Mar Ecol Prog Ser 81:25-30

Deibel D, Powell CVL (1987) Comparison of the ultrastructure of the food-concentrating filter of two appendicularians. Mar Ecol Prog Ser 39:81-85

Eppley RW, Reid FMH, Strickland JDH (1970) Estimates of phytoplankton crop size, growth rate, and primary production. In: Strickland JDH (ed) The ecology of the plankton off La Jolla California in the period April through September. Bull Scripps Inst Oceanogr Univ Calif 17:33-42

Fenaux R (1968) Appendiculaires (Campagne de la Calypso au large des côtes atlantiques de l'Amérique du Sud (1961-1962) (première partie)). Ann Inst Océanogr 45: $33-46$

Fenaux R (1993) The classification of Appendicularia (Tunicata): history and current state. Mem Inst Oceanogr 17: $1-123$

Fenaux R (1998) Life history of the Appendicularia. In: Bone Q (ed) The biology of pelagic tunicates. Oxford University Press, Oxford, p 151-159

Fenaux R, Dallot S (1980) Répartition des appendiculaires au large des côtes de Californie. J Plankton Res 2:145-167

Fenaux R, Bone Q, Deibel D (1998) Appendicularian distribution and zoogeography. In: Bone Q (ed) The biology of pelagic tunicates. Oxford University Press, Oxford, p 252-264

Fernández D, López-Urrutia Á, Fernández A, Acuña JL, Harris $R$ (2004) Retention efficiency of 0.2 to $6 \mu \mathrm{m}$ particles by the appendicularians Oikopleura dioica and Fritillaria borealis. Mar Ecol Prog Ser 266:89-107

Flood PR, Deibel D (1998) The appendicularian house. In: Bone Q (ed) The biology of pelagic tunicates. Oxford University Press, Oxford, p 105-124

Flood PR, Deibel D, Morris CC (1992) Filtration of colloidal organic matter by planktonic tunicates. Nature 355: 630-632

Frost BW (1972) Effects of size and concentration of food particles on the feeding behavior of the marine planktonic copepod Calanus pacificus. Limnol Oceanogr 17:805-815

Gorsky G (1980) Optimisation des cultures d'appendiculaires: approche du métabolisme de Oikopleura dioica. PhD thesis, l'Universite Pierre et Marie Curie, Paris VI

Gorsky G, Fisher NS, Fowler SW (1984) Biogenic debris from the pelagic tunicate Oikopleura dioica and its role in the vertical transport of a transuranium element. Estuar Coast Shelf Sci 18:13-23

Gorsky G, Chrétiennot-Dinet MJ, Blanchot J, Palazzoli I (1999) Picoplankton and nanoplanton aggregation by appendicularians: fecal pellet contecnts of Megalocercus huxleyi in the equatorial Pacific. J Geophys Res 104: 3381-3390

Harbison GR (1992) The gelatinous inhabitants of the ocean interior. Oceanus 35:18-23

Holm-Hansen O, Riemann B (1978) Chlorophyll a determination: improvements in methodology. Oikos 30:438-447

Hopcroft RR, Roff JC, Bouman HA (1998) Zooplankton growth rates: the larvaceans Appendicularia, Fritillaria and Oikopleura in tropical waters. J Plankton Res 20: 539-555

Karl DM, Bidigare RR, Letelier RM (2002) Sustained and aperiodic variability in organic matter production and phototrophic microbial community structure in the North Pacific subtropical gyre. In: Williams PJleB, Thomas DN, Reynolds CS (eds) Phytoplankton productivity: carbon assimilation in marine and freshwater ecosystems. Blackwell Science, Oxford, p 222-264

Kimmerer WJ (1984) Selective predation and its impact on the prey of Sagitta enflata (Chaetognatha). Mar Ecol Prog Ser 15:55-62

King KR, Hollibaugh JT, Azam F (1980) Predator-prey interactions between the larvacean Oikopleura dioica and bacterioplankton in enclosed water columns. Mar Biol 56:49-57

Knoechel R, Steel-Flynn D (1989) Clearance rates of Oikopleura in cold coastal Newfoundland waters: a predictive model and its trophodynamic implications. Mar Ecol Prog Ser 53:257-266

Landry MR, Kirchman DL (2002) Microbial community structure and variability in the tropical Pacific. Deep-Sea Res II 49:2669-2693

Landry MR, Haas LW, Fagerness VL (1984) Dynamics of microbial plankton communities: experiments in Kaneohe Bay, Hawaii. Mar Ecol Prog Ser 16:127-133

Lee S, Fuhrman JA (1987) Relationships between biovolume and biomass of naturally derived marine bacterioplankton. Appl Environ Microbiol 53:1298-1303

Lohmann H, Hentschel E (1939) Die Appendicularien im Südatlantischen Ozean. Wiss Ergeb Dtsch Atlant Exped 'Meteor' 13:153-243

López-Urrutia Á, Irigoien X, Acuña JL, Harris R (2003) In situ feeding physiology and grazing impact of the appendicularian community in temperate waters. Mar Ecol Prog Ser 252:125-141

Monger BC, Landry MR (1993) Flow cytometric analysis of marine bacteria with Hoechst 33342. Appl Environ Microbiol 59:905-911

Monger BC, Landry MR, Brown SL (1999) Feeding selection of heterotrophic marine nanoflagellates based on the surface hydrophobicity of their picoplankton prey. Limnol Oceanogr 44:1917-1927

Owen RW (1966) Small-scale, horizontal vortices in the surface layer of the sea. J Mar Res 24:56-66

Purcell J, Sturdevant MV, Galt CP (2004) The importance of appendicularians as prey of vertebrate and invertebrate predators: a review. In: Gorsky G, Deibel D, Bone Q, Youngbluth $M$ (eds) Response of marine ecosystems to global change: ecological impact of appendicularians. Gordon and Breach Scientific Publishers, Paris

Sato R, Tanaka Y, Ishimaru T (2004) Clearance rates of Oikopleura longicauda, O. rufescens and O. fusiformis. In: Gorsky G, Deibel D, Bone Q, Youngbluth M (eds) Response of marine ecosystems to global change: ecological impact of appendicularians. Gordon and Breach Scientific Publishers, Paris

Scheinberg RD (2004) Food web structure and trophic dynamics of a subtropical plankton community, with an emphasis on appendicularians. PhD thesis, University of Hawaii, Honolulu

Scheinberg RD, Landry MR (2004) Clearance rates and efficiencies of Oikopleura fusiformis on the natural prey assemblage of a subtropical coastal ecosystem. In: Gorsky G, Deibel D, Bone Q, Youngbluth M (eds) Response of marine ecosystems to global change: ecological impact of appendicularians. Gordon and Breach Scientific Publishers, Paris, p 203-228 
Selander E, Tiselius P (2003) Effects of food concentration on the behaviour of Oikopleura dioica. Mar Biol 142:263-270

Shalapyonok A, Olson RJ, Shalapyonok LS (2001) Arabian Sea phytoplankton during southwest and northeast monsoons 1995: composition, size structure and biomass from individual cell properties measured by flow cytometry. Deep-Sea Res II 48:1231-1261

Shelbourne JE (1962) A predator-prey size relationship for plaice larvae feeding on Oikopleura. J Mar Biol Assoc UK 42:243-252

Taguchi S (1982) Seasonal study of fecal pellets and discarded houses of appendicularia in a subtropical inlet, Kaneohe Bay, Hawaii. Estuar Coast Shelf Sci 14:545-555

Tiselius P, Petersen JK, Nielsen TG, Maar M and 8 others

Editorial responsibility: Otto Kinne (Editor-in-Chief), Oldendorf/Luhe, Germany
(2003) Functional response of Oikopleura dioica to house clogging due to exposure to algae of difference sizes. Mar Biol 142:253-261

Tokioka T (1960) Studies on the distribution of appendicularians and some thaliaceans of the North Pacific, with some morphological notes. Publ Seto Mar Biol Lab 8:351-433

Tomita M, Naonobu S, Tsutomu I (2003) Seasonal occurrence and vertical distribution of appendicularians in Toyama Bay, southern Japan Sea. J Plankton Res 25:579-589

Turner JT, Hopcroft RR, Lincoln JA, Huestis CS, Tester PA, Roff JC (1998) Zooplankton feeding ecology: grazing by marine copepods and cladocerans upon phytoplankton and cyanobacteria from Kingston Harbour, Jamaica. Mar Ecol 19:195-208

Submitted: March 22, 2004; Accepted: December 30, 2004 Proofs received from author(s): May 13, 2005 